\title{
Preparation of whey based custard apple (Annona squamosa L.) pulp beverage
}

\author{
DIPIKA D. KHODKE, K. U. BIDWE, R. R. SHELKE AND P. A. KAHATE
}

\begin{abstract}
The present investigation was carried out in the laboratory of Department of Animal Husbandry and Dairy science, Dr. Panjabrao Deshmukh Krishi Vidyapeeth, Akola during the year 2016-2017. During present investigation beverage was prepared with different combinations of whey and custard apple pulp as 97:03 $\left(\mathrm{T}_{1}\right), 94: 06\left(\mathrm{~T}_{2}\right), 91: 9\left(\mathrm{~T}_{3}\right), 88: 12\left(\mathrm{~T}_{4}\right)$ and 85:15 ( $\left.\mathrm{T}_{5}\right)$. For sensory evaluation the results revealed that overall acceptability scores obtained were 7, 7.5, 8.75, 7.75 and 7.25 for the treatment $\mathrm{T}_{1}, \mathrm{~T}_{2}, \mathrm{~T}_{3}$, $\mathrm{T}_{4}$ and $\mathrm{T}_{5}$, respectively. The treatment $\mathrm{T}_{3}$ scored significantly highest scores for flavour, colour, consistency and overall acceptability which were found superior amongst all the treatments. The beverage prepared from all combinations of whey and custard apple pulp was found acceptable. The cost of production per $\mathrm{kg}$ of beverage was increased with increase in the rate of addition of custard apple pulp. i.e. Rs.15.17 ( $\left.\mathrm{T}_{1}\right)$, Rs. $21.14\left(\mathrm{~T}_{2}\right)$, Rs. $27.11\left(\mathrm{~T}_{3}\right)$, Rs. $33.08\left(\mathrm{~T}_{4}\right)$ and Rs. $39.05\left(\mathrm{~T}_{5}\right)$.
\end{abstract}

KEY WORDS : Whey, Custard apple, Beverage, Blending, Sensory evaluation, Cost of production

How TO CITE THIS PAPER : Khodke, Dipika D., Bidwe, K.U., Shelke, R.R. and Kahate, P.A. (2017). Preparation of whey based custard apple (Annona squamosa L.) pulp beverage. Res. J. Animal Hus. \& Dairy Sci., 8(2) : 94-98 : DOI: 10.15740/HAS/RJAHDS/8.2/94-98.

Address for correspondence :

R. R. Shelke, Department of Animal Husbandry and Dairy Science, College of Agriculture, Dr. Panjabrao Deshmukh Krishi Vidyapeeth, AKOLA (M.S.) INDIA

Associated Authors' :

Dipika D. Khodke, K.U. Bidwe and P. A. Kahate, Department of Animal Husbandry and Dairy Science, College of Agriculture, Dr. Panjabrao Deshmukh Krishi Vidyapeeth, AKOLA (M.S.) INDIA 